\title{
ФОРМУВАННЯ ПРЕДМЕТНИХ КОМПЕТНТНОСТЕЙ УЧНІВ ОСНОВНОЇ ШКОЛИ У ПРОЦЕСІ ВИВЧЕННЯ ДИСЦИПЛІН ГУМАНІТАРНОГО ЦИКЛУ
}

У статті розкрито шляхи формування предметних компетентностей учнів основної школи у процесі вивчення украӥнської літератури, літературного краєзнавства та під час позакласного читання. Обгрунтовано мовно-літературні параметри роботи з художнім текстом.

Ключові слова: предметні компетентності, учні основної иколи, предмети гуманітарного цчиклу.

В статье раскрыты пути формирования предметных компетентностей учеников основной школь в процессе изучения украинской литературы, литературного краеведения и во время внеклассного чтения. Обоснованы языковые и литературные параметры работы с художественным текстом.

Ключевые слова: предметные компетентности, ученики основной школь, предметь гуманитарного ичикла.

In the article the way of formation of subject competence of pupils in primary schools studying Ukrainian literature, local history and literature at home reading. Justified by the language and literary options for working with literary texts.

Key words: subject expertise, primary school pupils, the humanities.

Сучасний етап розвитку суспільства супроводжується процесами інтеграції та глобалізації, переорієнтацією суспільних відносин, розширенням культурних меж. Відбуваються зміни й у сфері освіти. Саме освіта постає визначальним чинником політичної, соціально-економічної, культурної та наукової життєдіяльності суспільства, оскільки відтворює й нарощує його інтелектуальний, духовний та економічний потенціал.

Україна початку XXI століття перебуває на етапі трансформації суспільного розвитку й радикальних перетворень у сфері освіти. Соціальні проблеми зумовлюють вироблення нових підходів

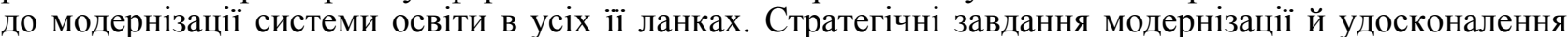
освіти передбачають реформування iї концептуальних, структурних, організаційних засад; розбудову освіти, ідеологічною основою якої повинна стати національна ідея. Переосмислення означених реалій та послідовне обгрунтування нового світоглядно-філософського дискурсу в розвитку освіти викладено українськими вченими $\quad$ В. Андрущенком, $\quad$ I. Зязюном, В. Огнев’юком, О. Пометун, О. Савченко та іншими.

У період оновлення всіх аспектів життєдіяльності суспільства й реалізації актуальних завдань Державної національної програми «Освіта» («Україна XXI століття»), Національної доктрини розвитку освіти України в XXI столітті, основних положень загальноєвропейських рекомендацій 3 мовної освіти зумовлюють певним чином переглянути усталені погляди на процес навчання гуманітарних предметів і визнати читацькі, комунікативні та соціокультурні вміння пріоритетними якостями учня основної школи.

Одним із пріоритетних завдань навчання гуманітарних предметів визнається формування в учнів предметних компетностей, тим самим сучасна концепція гуманітарної освіти робить важливий акцент на необхідності не обмежувати вивчення гуманітарного предмета вербальним кодом, а формувати у свідомості учня «картину світу», притаманну представникові певної культури й певного соціуму.

Загальні аспекти ключових компетентностей знайшли послідовне висвітлення в роботах А. Вербицького, П. Горностая, В. Донія, І. Срмакова, І. Зимньої, В. Ляшенка, Г. Несен, О. Овчарук, В. Серікова, Л. Сохань та інших.

Питання про народознавчий, етнолінгвістичний та соціокультурний аспекти навчання гуманітарних дисциплін, про зміст предметної компетентності знайшло теоретичне обгрунтування у працях багатьох учених (М. Аріян, А. Богуш, Є. Верещагін, І. Воробйова, Н. Гез, В. Кононенко, О. Леонтьєв, В. Сафонова та ін.).

У контексті навчання соціокультурна компетенція розглядається в початковій та основній школі (А. Богуш, I. Єрмаков, О. Коломінова, 3. Корнаєва, М. Левшин, С. Ніколаєва, М. Пентилюк та ін.).

Таким чином, соціальна й педагогічна значущість проблеми формування предметних компетентностей та необхідність визначення основних їх характеристик і особливостей організації навчального процесу, який забезпечував би достатній рівень сформованості в учнів предметних компетентностей відповідно до основної мети навчання гуманітарних предметів - формування національно свідомої особистості, яка органічно входить до соціокультурної дійсності й готова до полікультурної комунікації.

Mета статті - розкрити шляхи формування предметних компетентностей учнів основної школи на предметах гуманітарного циклу.

Завдання сучасної української освіти полягає, передовсім, у формуванні особистості з гнучким розумом, із швидкою реакцією на все нове, з повноцінними, розвинутими потребами подальшого 
пізнання та самостійної дії, з добрими орієнтувальними навичками й творчими здібностями. Духовне відродження українського народу неможливо уявити без впливу художньої літератури на формування національної свідомості, оскільки література є одним із активних чинників суспільного виховання - совісті, моралі, загальнолюдських цінностей. Зміни в усіх сферах нашого життя безпосередньо впливають на літературну освіту школярів, адже література - це відображення в художньому стилі життя людини та суспільства $з$ усіма складнощами і проблемами. Однак, щоб література здійснювала свою виховну роль, треба виробити у людини вміння читати художні твори, належним чином сприймати дійсність, відображену в художній формі, сформувати прагнення брати приклад із позитивних героїв - виховного ідеалу. Нині стоїть завдання побудувати навчальновиховний процес таким чином, щоб розвивати в учнів пізнавальний інтерес, вміння самостійно поповнювати знання, орієнтуватися в потоці наукової та політичної інформації. Усе це актуалізує питання формування уважного читача 3 розвинутими творчими, розумовими, пізнавальними здібностями, який у процесі роботи над твором, максимально наближаючись до авторського задуму, готовий до критичної, виваженої оцінки, обстоювання власної думки, при цьому врівноваживши у свідомості інші позиції предмету обговорення.

Процес формування в учнів основної школи предметних компетентностей на уроках літератури передбачає розв'язання таких завдань:

- зацікавити учнів читанням;

- $\quad$ розвивати інтерес до створення постійної потреби в читанні;

- навчити вибирати літературу, враховуючи вікові та особистісні інтереси;

- створити належні психолого-педагогічні умови для сприйняття, розуміння та оцінки прочитаного;

- формувати навички аналізу художнього твору;

- організовувати дослідницьку роботу учнів;

- $\quad$ розвивати усне та писемне мовлення учнів;

- працювати над постійним удосконаленням естетичного смаку учнів.

Ефективними методами в системі літературознавчої підготовки учнів $є$ : група діалогічних методів, обговорення, індукція, дедукція, аналіз, синтез, група компаративних методів, дослідницькі методи (індукції, дедукції, аналізу, синтезу, абстрагування, конкретизації, аналогій, моделювання, узагальнення, група спеціальних методів, пов'язаних 3 аналізом художнього тексту, тобто композиційний, пообразний, порівняльний та узагальнюючий аналіз тексту, аналіз біографії на основі принципів цілісності, єдності автора і тексту, аналізу антиномій, обговорення, встановлення наслідкових зв'язків у літературній традиції регіону тощо.

Важливими засобами навчання є: стенди, експозиції, структурно-логічні схеми блок-схеми, що ілюструють нормативні освітні документи, літературні карти регіонів, музейні експонати.

Інтерпретація тексту - це вертикальне дослідження тексту з виявлення глибинних підтекстових значень, авторської оцінної позиції, з'ясування того естетичного ефекту, що виникає в результаті взаємодії художніх засобів. Основним прийомом є пошук синтезуючого початку в системі цих засобів, тобто не лише розгляд загальної образності, а насамперед аналіз ключових творів і фігур [1, c. $42 ; 7]$.

Основними й найбільш доцільними прийомами роботи над виробленням умінь і навичок аналізу художнього тексту є:

спостереження над використанням мовних одиниць різних рівнів у тексті художнього твору, що дає змогу формувати в старшокласників увагу до слова, осмислювати його виражальну цінність;

стилістичний аналіз, що сприяє усвідомленню художньої функції слова, розумінню доцільності вибору письменником відповідних мовних одиниць, використання їх у тій ролі, яка зумовлюється конкретним текстом;

використання елементів лінгвістичного коментаря, що сприяє ознайомленню учнів із системністю різних мовних одиниць, залежністю від літературного та ідейно-естетичного рівнів тексту [9].

Упровадження в навчальну діяльність названих прийомів буде ефективним за умови, якщо вчитель заздалегідь орієнтуватиметься, при вивченні якого твору та 3 якою метою доцільне їх використання. Увага до мовних особливостей художнього твору формується під час здійснення порівняльного аналізу мовних засобів творів письменників рідного краю. Функціональне призначення виражальних мовних засобів можна встановити у процесі стилістичного аналізу тексту, що дозволяє побачити, як інколи один і той же засіб виконує у певному контексті різні функції.

На думку методистів, зміст аналізу тексту полягає у визначенні лексичних засобів, що дозволяє визначити основні принципи лінгвістичного аналізу тексту (вироблення лексико-стилістичної пильності; точність у з'ясуванні семантики слова; увага до незнайомих слів; спостереження над особливостями сполучення (звичного / незвичного) слів; увага до значення слова в контексті; увага до лексичного багатства, лексичних шарів; вироблення чуття стилю; вироблення вмінь і навичок створювати власні висловлювання, які б характеризувалися точністю, правильністю, образністю, виразністю, доречністю; розвиток естетичних почуттів, творчих здібностей учнів). 
Процес засвоєння виражальних засобів тісно пов'язаний із формуванням образного мовлення, яке характеризується свідомим ставленням до мови, глибоким знанням, розвиненим мовленням, а отже, $\mathrm{i}$ мисленням, інтелектом, емоційною сферою, емоційно-естетичним сприйняттям мови й мовлення, що передбачає чутливість до слова, здатність відчувати й розуміти всі відтінки його значення, відчувати красу рідної мови, іiі багатство. Багатоаспектність і складність проблеми розвитку образного мовлення зумовили iї розгляд із різних позицій: збагачення словникового запасу учнів на різних етапах мовленнєвого розвитку; культура мовлення; психологічні засади розвитку мовлення; функціонування текстів художнього стилю; розроблення мовного компонента загальноосвітньої підготовки учнів; комунікативний аспект вивчення мови $[2 ; 5 ; 9 ; 12]$.

Виражальні засоби оптимізують вироблення образного мовлення, в якому передбачається вживання слів і словосполучень у незвичайному метафоричному значенні, що дає змогу художньо відтворювати дійсність. У лінгвістичній науці образність розглядається передовсім як властивість слова і як комунікативна якість мовлення, має безпосереднє відношення до лінгвістики тексту, семантичних перетворень, стилістичних зрушень.

Взаємозв'язок мовлення i мислення розглядався у багатьох дослідженнях лінгвістів та лінгводидактів, що дозволяє витлумачувати образне мислення як складне гетерогенне психічне утворення, основна функція якого полягає в оперуванні почуттєвими (наочними) образами на основі образів, уже наявних у суб'єктивному досвіді людини. В образному мисленні представлені й функціонують у складній єдності різні психічні процеси: сприйняття, пам'ять, уявлення, уява.

Психологи визначають, що змістом образного мислення є різні чуттєві враження, які інтегруються в цілісний образ. Основу образу становлять зорові враження, оскільки саме зорова система найбільш потужний засіб сприйняття, зберігання й переробки всієї наукової інформації. Вона ж $\epsilon$ основою для орієнтації людини в розмаїтті навколишнього світу: через наочність у навчанні зорова система стає основним почуттєвим каналом засвоєння образномовленнєвих умінь.

Образне мислення забезпечує функціонування таких мовленнєво-мислительних процесів, які позитивно впливають на розвиток і вдосконалення образності мовлення особистості. Процес породження образного мовлення грунтується на відображенні дійсності в свідомості дитини. Невід'ємним механізмом образності є уява. Уява включається тоді, коли проблемна ситуація характеризується відсутністю потрібної повноти знань і неможливістю передбачити результати діяльності за допомогою організованої системи понять (мислення). Уява забезпечує моделювання поведінки, процесів або об'єктів. Створювані уявою вербальні образи стають основою образного мовлення індивіда. У психологічному аспекті образне мовлення витлумачується як різновид зв'язного мовлення, продукування особистістю нових оригінальних мовленнєвих сюжетів (із використанням показників образності) на основі образного мислення, продуктивно-творчої уяви, фантазії, що супроводжується інтелектуально-мовленнєвою активністю і словесною творчістю [3, c. $238 ; 4]$.

Поняття «образність», «образне мовлення» вчені розглядають у контексті акцентування на мовних засобах, які використовуються в будь-якому художньому тексті [7; 10].

Виразники образності становлять усталені в писемному мовленні різні щодо рівня переосмислення чи асоціативності слова та вислови, які за допомогою певних естетичних властивостей (яскравість, незвичність у поєднанні з іншими словами, метафоричність, емоційність тощо) образно (картинно) передають думки певної особи-мовця, викликають певні емоції та почуття, збуджують фантазію.

Формуванню предметних компетентностей учнів основної школи сприятиме активне упровадження літературного краєзнавства на міжпредметній основі. Осмислення ролі літературного краєзнавства в інтегративній мовно-літературній освіті на тлі культури, пошук автентичності неможливі без живого інтересу до літературної та історичної спадщини рідного краю. В останні роки перед нашою державою постало завдання презентації власного історико-культурного надбання у європейській світовій спільноті. Це можливо не лише за умови проведення узагальнюючих інтегративних досліджень літературного процесу України загалом, але й за умов глибокого, системного вивчення літератури кожного окремого регіону нашої держави.

Вивчення літератури рідного краю сприяє осмисленню історії рідного краю, його духовного життя, національних традицій, формуванню національної свідомості, патріотизму та є могутнім виховним засобом, що стимулює самовдосконалення й саморозвиток особистості учнів, для яких приклад вихід-ця з рідного краю є дієвою моральною школою [8].

Мета впровадження літературного краєзнавства на уроках рідної мови певною мірою подвійна,що полягає у розширенні світогляду учнів, сприянні патріотичному й естетичному вихованню, формуванню художніх смаків й активізації знань учнів із рідної мови, підвищення результативності уроків.

Літературне краєзнавство розкриває великі можливості для інтелектуального, морального, естетичного розвитку, формує патріотичні почуття учнів, любов до рідного краю, своїх земляків. Збагачуючись знаннями про рідний край на уроках мови та літератури, учні зростають духовно, 
задумуються над сенсом життя та своїм походженням. Окрім того, розвивають культуру усного й писемного мовлення, вчаться вільно володіти мовою [8, с. 108-109; 10].

Нині активізуються естетичні пошуки, утверджується розкутість художнього мислення, інтеграція у світовий літературний процес із філософсько-естетичним розмаїттям. Художня свідомість сучасного письменства зазнає глобальних змін та переорієнтації, відбувається переоцінка життєвих та естетичних цінностей - зрештою, завершується ще одна епоха і на наших очах постає й формується нова якість художнього слова [6].

Оптимальне поєднання літературно-краєзнавчого й мовного аспектів у процесі вивчення української літератури можливе з урахуванням таких умов:

- у процесі вивчення програмового матеріалу, формування змісту літературного краєзнавства як потенційного дидактичного матеріалу в системі мовленнєвої підготовки учнів виходити не тільки 3 критеріїв походження, перебування чи проживання письменників рідного краю в рамках географічної території, як із культурологічних засад, дотичності до звичаїв та традицій регіонального культурного осередку;

- забезпечувати проблемний, варіативний, інтегративний, дослідницько-пошуковий i творчоевристичний характер методів, прийомів, форм та засобів його використання;

- орієнтуватися в системі мовленнєвої підготовки учнів на зміст навчального матеріалу на програмовій та краєзнавчій основі «Література рідного краю»;

- залучати учнів до комплексних лінгвістичних, історико-літературних, етнографічнокультурних наукових досліджень, пов'язаних із рідним краєм.

Констатуємо потребу науково обгрунтування доцільності вивчення літератури рідного краю на уроках рідної мови як засобу формування художніх смаків учнів, а також допомогти вчителямсловесникам знайти найбільш ефективні шляхи, які зроблять літературне краєзнавство цікавим i корисним. Якими б досконалими не були шкільні програми, вони не можуть охопити всієї літературної творчості кожного куточка України. Тому, на нашу думку, необхідно проводити літературно-краєзнавчу роботу на уроках рідної мови в школі у таких напрямках: а) на уроках української мови, де учні виробляють лінгвістичні вміння і навички під час спостереження над художнім текстом; б) на окремих уроках літератури рідного краю, які потребують спеціальної підготовки, пов'язаної з пошуком краєзнавчих матеріалів і на які програмою визначено певну кількість годин; в) у позакласній роботі, застосовуючи різні форми, методи і прийоми проведення позакласних заходів: вивчення літературної географії краю; виготовлення альбомів; зустрічі 3 людьми, які знали письменників, запис їхніх спогадів; зустрічі з письменниками; екскурсії в музеї; походи пам'ятними літературними місцями рідного краю; літературні вечори; записи фольклору тощо.

Потужний потенціал з виховання уваги до художнього слова має позакласне читання. Важливою ланкою літературної освіти учнів є уроки позакласного читання, які є формами організації читацької діяльності, інформаційно-навчального забезпечення, звітів про виконання (власне обговорення прочитаного) та узагальнення проведеної роботи [11; 12]. Саме вони, на думку провідних сучасних методистів, найкраще формують читацьку компетентність учня, що має такі складові:

- освітньо-змістовий аспект читацької культури - загальна начитаність (літературна ерудиція, знання текстів прочитаних творів), потреба в читанні, фактичні знання 3 літератури, літературної критики, оволодіння логікою аналізу творів);

- практичний аспект самостійного читання - уміння інтерпретувати, висловлювати роздуми щодо певного літературного явища, обговорювати, дискутувати, аргументовано доводити власну думку;

- ціннісно-орієнтаційний аспект читацької культури - здатність сприймати конкретні художні твори, оцінювати їх на основі власних почуттів [10].

Г. Токмань радить учителеві, готуючи систему роботи з позакласного читання, розвивати всі елементи читацької культури учнів, обирати твори зі «Списку рекомендованої літератури для позакласного читання» із навчальної програми, орієнтуючись на конкретний клас та індивідуальності учнів [11, 128]. У відгуку на «Концепцію реформування літературної освіти в середній школі (предмет - українська література)» Григорія Клочека методист зазначає: «Вивчення української літератури у школі має завершитися сформованістю в молодої людини сталої потреби в читанні української художньої книжки. Потрібно виховати внутрішню необхідність повертатися до класики для іiі нового сприйняття, а також пробудити інтерес до сучасного літературного процесу - нових творчих здобутків авторів, вивчених у школі, зацікавити новими іменами, що заявляють про себе яскравими художніми полотнами. Насолода під час читання художнього твору, відчуття духовного збагачення від спілкування 3 українською книжкою, пережиті у шкільні роки, стануть основою повсякчасної любові до рідного слова» [11, с. 24]. Без ознайомлення учнів із сучасним літературним процесом неможливо виховати активного читача. Переконані: доцільно виносити на уроки позакласного читання цікаві твори сучасників, що викликають суспільний резонанс, дискусії й захоплення вчителя як читача.

Формування предметних компетентностей учнів основної школи буде оптимальним за умови врахування таких аспектів: організація роботи учнів із художнім текстом на уроках літератури, 
літературного краєзнавства, під час позакласного читання. Гуманітарна парадигма визначає оптимальним залучення учнів до роботи з текстом на міжпредметній основі (на уроках мови).

\section{Література}

1. Борисюк I. В. Роль тексту на шляху формування комунікативної компетентності учнів / I. В. Борисюк // Мовознавство. - 1998. - № 1. - С. 41 - 54. 2. Введенская Л. А. Культура и искусство речи / Л. А. Введенская. Ростов-на-Дону : Феникс, 1995. - 576 с. 3. Вікова психологія / за ред. Костюка Г. С. та ін. - К. : Рад. школа, 1976. - 270 с. 4. Возрастная и педагогическая психология : [учеб. пособ. для студ. пед. ин-тов] / М. Матюхина, Т. Михальчик. - М. : Просвещение, 1984. - 256 с. 5. Грибан Г. Взаємозв'язок у вивченні мови та літератури / Г. Грибан // Дивослово. - 1998. - № 23. - С. 19-22. 7. Концепція літературної освіти в 12-річній загальноосвітній школі. - 2002. - № 1. - С. 2-13. 6. Мироненко Т. Формування образного мислення учнів на уроках лексикології / Т. Мироненко // Дивослово. - 2003. - № 1. - С. 37-41. 7. Пасічник Є. А. Літературне краєзнавство в школі / Є. А. Пасічник. - К. : Рад. школа, 1965. - 136 с. 8. Ситченко А. Л. Методика навчання української літератури в загальноосвітніх закладах [Текст]: [навч. посіб. для студ.-філологів] / А. Л. Ситченко. К. : Ленвіт, 2011. - 291 с. 9. Степанишин Б. І. Нові підходи до викладання української літератури Б. І. Степанишин // Дивослово. - 1995. - № 1. - С. 44-46. 10. Токмань Г. Вікова психологія як наукове джерело методики викладання літератури / Ганна Токмань // Дивослово. - 2003. - № 6. - С. 23-29. 11. Токмань Г. Л. Навчання української літератури: розвивати не втрачаючи / Г. Л. Токмань // Дивослово. - 2011. - № 12. - С. 32. 